\title{
James Cone vis-à-vis African Religiosity: A decolonial perspective
}

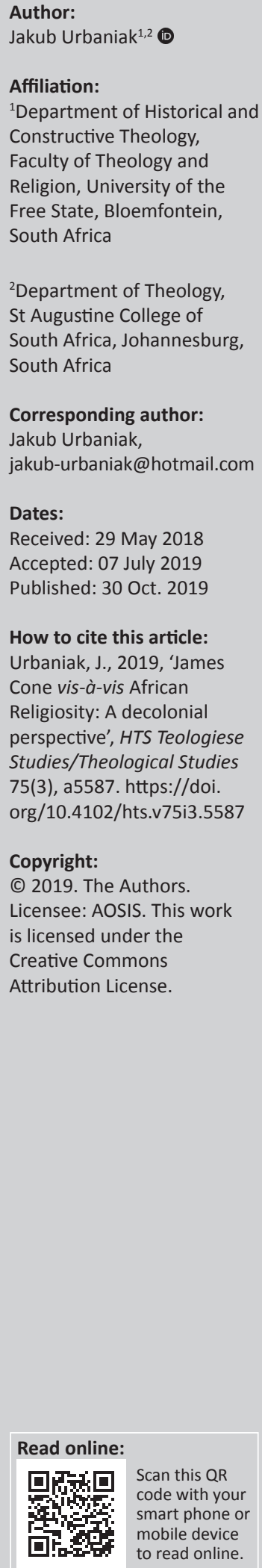

This article builds on my recent engagement with James Cone's binary view of Africanness and Christianity which focused on his Western locus of enunciation and the criticism he received from his African American colleagues. I believe that analogical questions regarding Christian theology's attitude towards Africanness in general and African religiosity in particular present themselves to us who live in and try to make sense of South African reality today, including white people like myself. I start by introducing a decolonial perspective as it manifests itself through the recent \#MustFall student movements. In this context, I offer three theses regarding the decolonial perspective on African religiosity, each of which constitutes a more or less direct critique of Cone's ambivalent attitude towards Africanness, and African Traditional Religions in particular. The first thesis concerns the distinction between postcoloniality and decoloniality; the second thesis concerns engaging African religiosity as a requirement for decolonising Christian theology; and the third thesis concerns problematising the relationship between the categories of blackness and Africanness.

Keywords: James Cone; Black Theology; African Religiosity; Decolonial; \#MustFall Movement; Fallism; African Traditional Religions; African Initiated Churches; Decolonisation; South Africa.

\section{Introduction}

Recently, I had an opportunity to engage James Cone's binary view of Africanness and Christianity, focusing on his Western locus of enunciation and the criticism he received from his African American colleagues (notably Gayraud Wilmore, Cecil Cone and Charles Long). As I stated at the end of my article, the ultimate reason why these and similar questions matter to me - and the reason why I chose to probe Cone's attitude towards Africanness in general and African religiosity in particular - is that, I believe, analogical questions present themselves to us who live in and try to make sense of South African reality today, including white people like myself (Urbaniak 2018b:193-194). Here I wish to elaborate on this statement by offering a more contextually relevant insight into Cone's attitude towards African religiosity.

Where does Cone's binary view of Christianity and Africanness leave the experiences of various African peoples around the globe, especially in Africa itself, who have fought against colonial oppression and who continue to fight against various forms of imperial injustice emblematised by whiteness? To say that these experiences transcend those of African Christians (the black churches), and even what can be labelled 'Christian' in the case of the latter, would be stating the obvious. Indeed, the experiences of African people cannot be separated from the astonishingly rich and diverse facets of African culture and religiosity, ${ }^{1}$ including African Traditional Religions (ATR). But, to paraphrase Vellem's (2014:6-7) question: What does the relationship between Christian faith and African religiosity really signify? Does it imply the 'inclusion' of the black African dispensation in the central tenets of Christianity, or does it signify the liberation of African religiosity within its tenets? Not least, is African religiosity an embodiment of the Christian-faithdecolonised-and-liberated in the present-day African contexts, or not?

This article offers three theses regarding the decolonial perspective on African religiosity, each of which constitutes a more or less direct critique of some of the blind spots in James Cone's development of the grammar of black theology of liberation (BTL), and more specifically of Cone's ambivalent attitude towards Africanness, and ATR in particular. The first thesis concerns the distinction between postcoloniality and decoloniality; the second thesis concerns engaging

1.Although the two cannot be simply equated, to claim that, in an African context, separating them is trying to achieve the impossible amounts to truism. As Mumo (2018:198), among many others, reiterates, 'culture and religion are interwoven in Africa and shape identity'. What is more, any such categorisation should be viewed with suspicion as an attempt to impose Western dualistic concepts on African reality. 
African religiosity as a requirement for decolonising Christian theology; and the third thesis concerns problematising the relationship between the categories of blackness and Africanness (or Africanity).

\section{Engaging African Religiosity from a decolonial perspective}

Before I even try to wrestle with the questions surrounding the decolonial project, I have to answer a meta-question concerning my own location. Put simply: Why should I be reflecting on the experience of African people, African religiosity and ATR? Neither of these are my location or field of academic expertise. I am a white male, with Western theological training (flavoured by the parochial tendencies of Polish Catholicism), who was sent to South Africa as a volunteer in 2010 by a French non-government organisation and stayed on ever since. I could theorise here about my understanding of and aspiration for being a good ally to black Africans with whom I share my daily life. But all too often such attempts lapse into a caricature of allyship, or what McKenzie (2015) aptly described as an 'ally theatre'. So let me just say that I consider it my responsibility to be part of the decolonial project in South Africa. The most prominent expression of this project in recent times has been the university protests organised by the members of various \#MustFall movements, protests which have gripped our national imagination since 2015.

In the narrow technical sense, fallism can be seen as 'a discursive tool to rattle the ideological complacency of the postapartheid university' (Ndelu 2017:21). The most frequently recurring demands of the protesting students across the country include (1) free, decolonised education for all; (2) the immediate clearance of historical student debt; and (3) \#EndOutsourcing of allied university workers (Ndelu 2017:15). But from the broader social perspective, it would be more adequate to describe fallism as a multifaceted movement, which is 'part of a larger struggle against the globalised system of racist capitalism' (Ndelu 2017:21). This is what I mean in this article when I refer to 'a decolonial perspective'. Put simply, it is a perspective which underlies a new form of informal yet radical anti-racist politics advanced by the South African students under the umbrella of various \#MustFall formations (Chikane 2018).

As a white male and a cultural outsider who lives in this country, I see myself primarily as an 'object' of that project. That is to say, I am the one to be decolonised. And yet this cannot happen unless I engage in that process deliberately as an agent. Far from claiming to be part of the \#MustFall movement, and even farther from making any pretence to authority regarding the decolonial turn which is at stake, ${ }^{2} \mathrm{I}$ simply attempt to make sense of the rationale behind fallism as well as the revolutionary call by its protagonists.

2.1 take seriously Cone's (1997:20) contention that 'any advice from whites to blacks on how to deal with white oppression is automatically under suspicion as a clever on how to deal with white oppression is automatically under suspicion as a clever
advice to further enslavement. Furthermore, it is white intellectual arrogance which advice to further enslavement. Furthermore, it is white intellectual arrogan
Listening to the voices of the protesting students, I have been seeking to internalise their call and answer it.

And so I am learning how to fall upward, to use Richard Rohr's (2011) felicitous expression. My hope is that my falling upward may leave open spaces that have been previously occupied by whiteness, patriarchy, heteronormativity, colonialism and other exclusionary systems of which I, as a white male, am an emblem. It is up to the students, among other black South Africans, to fill those spaces with themselves, with 'things, shapes, people [they] can recognise' (Conrad et al. 2017:50).

As for me, questions that trouble me most these days concern the role of white people and whiteness vis-à-vis the decolonial project. Are we going to play our role in what appears as an inevitable revolution or resist it? I firmly believe that as white people we are capable of rejecting whiteness. While awareness of our complicity in the unjust status quo is a necessary condition of our active engagement, and here the significance of the individual conscientisation cannot be overestimated, ultimately whiteness has to be denounced and voided on the institutional level, for this is where it preserves and reinforces itself. And this is where my personal journey and my academic interest in Christianity's attitude towards African religiosity converge. The remainder of this article is dedicated to highlighting three theses regarding the decolonial perspective on African religiosity, which can be seen as a fruit of my ongoing effort to make sense of this convergence. Cone's binary view of Christianity and Africanness will remain in the background of this discussion, more as its dialectic point of reference than its proper focus.

Thesis one: Giving Africanness, and African religiosity in particular, its due place in theological reflection requires a methodological shift from a postcolonial critique to a decolonial turn.

Commenting on the differences between postcoloniality and decoloniality, Mignolo (2011:xxiii) posits that 'although both projects drink from the same fountain they are grounded in a different genealogy of thoughts and different existential'. Sithole (2014:34-37) elucidates this distinction on three accounts, namely, genealogy, trajectory and horizon.

Regarding genealogy, 'postcoloniality can be traced from the canonical works of Edward Said, Homi Bhabha and Gayatri Spivak who still remain prominent even though the trajectory of postcoloniality varies' (Sithole 2014:34; cf. also Ashcroft, Griffiths \& Tiffin 2006:36-44). Although widely different in theoretical approaches, these three authors 'fashioned a ... deconstruction of Anglo-American hegemony in their own terms' (De la Campa 2008:438-439). Concerning the genealogy of decoloniality, Sithole (2014) refers to a plethora of African intellectuals:

The contours that shape the landscape of decoloniality can be traced from Steve Biko, Bernard Magubane, WEB Du Bois, 
Frantz Fanon, Ihechukwu Madubuike, V-Y Mudimbe, Paul Zeleza, Anibal Quijano, Linda Alcoff, Archie Mafeje, Walter Rodney, Kwame Nkrumah, Cheikh Anta Diop, Aimé Cesairé, Ramon Grosfoguel, Ngũgĩ wa Thingo'o, Chinweizu, Walter Mignolo, Enrique Dussel, Nelson Maldonado-Torres, and Lewis $\mathrm{R}$ Gordon to name but a few. The aforementioned thinkers come from different thought traditions and different geographies but they pursue one mission that is intentional in their work decoloniality. (p. 35)

Subtle yet consequential discrepancy between the two projects is manifested in their different trajectories.

Put simply, while postcoloniality is (still) caught in many ways within the Euro-North American matrix, decoloniality is operating outside that matrix by emphasising its nonWestern locus of enunciation (De la Campa 2008). Both projects stem from and provide theoretical framework for the resistance of the imperial power by the subjects who are wronged by that power. As a body of work, postcoloniality seeks to break-with colonial assumptions of Euro-North American political and cultural criticism. However, even though its epistemic locus is counter-hegemonic by form and content, postcoloniality originates for the most part from the Euro-North American English academic departments (Hume 2008:395). It is, therefore, the "Third World [sic] voice inside the Euro-North American empire' (Sithole 2014:35). Decoloniality, by contrast, 'stands outside the Euro-North American empire through border-gnosis' (Sithole 2014:35).

Further differences can be noted with regard to the horizon of each project. Through its focus on cultures and texts, postcoloniality remains essentially an epistemic project. In turn, decoloniality, which privileges people as subjects of history and their existential conditions, 'became an epistemic and political project' (Mignolo 2011:xxv, [author's added emphasis]). While the former calls for the transformation of the structure to solve problems, the latter calls for the structure to be destroyed to create new forms of lives (Sithole 2014:36). Thus, the decolonial project aims to unmask coloniality wherever it seeks to hide itself, to render it visible by exposing both its rhetoric and reality (Maldonado-Torres 2008:382), with a view to ultimately overturn the status quo (cf. Chikane 2018:2). Lastly, decoloniality calls for the end of the universal. Instead, it is in favour of many worlds or rather 'the world into [which] that many worlds fit - pluriversality' (Sithole 2014:37).

Qualifying Cone simply as a postcolonial, rather than a decolonial thinker, would be perhaps oversimplifying and thus problematic. But as far as this distinction is concerned, I think it is fair to say that Cone's ambivalent attitude towards African religiosity is representative of (or at least shares some important characteristics with) a postcolonial critique, while falling short of at least three key markers of a decolonial dynamic.

Firstly, as we have seen, decoloniality as a standpoint 'does not hide its geography and biography' (Sithole 2014:36); rather, decolonial authors proudly reveal their non-Western locus of enunciation. As I argued elsewhere, Cone's location remains essentially Western, and it is specifically Western Christianity which appears as his chief locus of enunciation (Urbaniak 2018b:187-190). ${ }^{3}$ As decolonial thinkers remind us, it was the same Western Christianity that 'became an expansionist religion concomitant with modernity, but also with terror as experienced by black Africans' (Vellem 2014:1).

Secondly, in his theological thinking, Cone fails to privilege African people, in their actual existential conditions, as subjects of history. ${ }^{4}$ There is no doubt he associates context and theology (Antonio 2018). But he falls short of his own standards when it comes to bringing to the fore and doing justice to those cultural and religious aspects of Africanness that connect the transatlantic contexts in which black people's humanity is denied and commodified. Telling in this context is the fact that indigenous culture and religion do not feature in Cone's (1979:179) understanding of the oneness of the 'black world' and its common historical option. Reading between the lines of Cone's black theology (BT), one gets the impression that while Christianity, including the preferential option for the poor and the promise/task of liberation, has a universal potential to unite, culture (Africanness) constitutes the principle of individuation, if not division.

Perhaps even more fundamentally, Cone's (1979:180) commitment to the universality of the Christian claim and his consequent failure to acknowledge indigenous cultures and religions as 'pluriversal worlds' in their own right (Urbaniak 2018b:177) remain at odds with decoloniality's rejection of the idea of the universal as instrumental in reifying 'the conception of the world informed by coloniality' (Sithole 2014:37; cf. also Mignolo 2011:xxiii-xxv).

Thirdly, on a more basic level, it is the very fact that Cone offers a critique of the West that disqualifies his BT as a (purely) decolonial project (cf. Antonio 2018). As Vellem (2014:4) puts it, 'Black Consciousness requires one to grasp the internal logic of Western superiority and debunk it'. In the same vein, Kobo (2018) argues that the West does not deserve critique from (what it considers) the margins, because

3.1 do not refer here to the fact that Cone was geographically located in the west but rather I argue that Cone's location as a theologian remained in essence Western, rather lath regard to his cultural and religious identity (i.e his blackness and his both with regard to his cultural and religious identity (i.e. his blackness and his Christianity). As I posit elsewhere, 'once Cone found Christ "in black people's struggle for freedom" (Cone 1986:43), he has never felt inclined to seriously consider black people's experience at large (meaning also beyond Christian faith and outside the American context) as a theological locus' (Urbaniak 2018b:187) After his epistemic shift from white (notably Barthian) theology that he learnt at Garrett to 'the theology of the black experience' (Cone 1986:45), it was mainly the slave religion as well as the civil rights and Black Power movements that constituted 'a reservoir of BT insofar as they found expressions in the black church's experience or, at least, proved compatible with and conducive to its struggle' (Urbaniak 2018b:187-188). I further substantiate this point by highlighting the central position that the notions of 'critique' and 'confession' occupied in Cone's frame of reference (2018b:188-190).

4.As I note elsewhere, 'Colonial history compels one to see Africanness and Christianity always as "two parties of incommensurate power"' (Comaroff \& Comaroff 1988.6). While missionaries were 'acutely aware of their capacity to "maroff 198.6). While missionaries were "acutely aware of their capacity to "make history," Africans consistently were treated as "objects of Christian mission" (Maluleke 2000:36). Even today these dynamics are at work in many ways including totally new and different ways with regard, for instance, to the loca Charismatic and Pentecostal churches, many of which are financially dependen upon and thus controlled by their American (not seldom ultra-fundamentalist) mother-churches' (Urbaniak 2018a:135). 
'critique might suggest that we [in this case, African women] are part of the system'.

And yet, on the other hand, what brings Cone's views somewhat closer to a decolonial perspective, I would argue, is the fact that he formulates his BT not as a purely epistemic project (i.e. a critique), and certainly not as a project revolving around some kind of other-worldly spirituality, but as a Christocentric and therefore a political one (indeed, at times, a revolutionary one). For instance, addressing African theologians gathered in Ghana in 1977, Cone (1979) stated that:

[I]nternational economic and political arrangements require a certain kind of African and black nationalism if we are to liberate ourselves from European and white American domination ... Oppression ceases only when the victims accumulate enough power to stop it. (pp. 178-179)

In the same address, referring to Canon Burgess Carr's (1974:78) distinction between the 'selective violence employed by the Liberation Movement' and the "'collective vengeance" perpetrated by the South African, Rhodesian, and Portuguese regimes in Africa', Cone corroborates Carr's contention that 'any outright rejection of violence is an untenable alternative for African Christians' (Cone 1979:181). Indeed, Cone believes that 'even black rebellion could (should) be seen as God's liberating work' (Engdahl 2017:3; cf. Cone 1997:38).

More broadly, rejecting Mbiti's critique of South African BT as misplaced, Cone asserts that 'the theme of liberation, as interpreted by the particularity of the African economic and political situation, provides the most creative dimension for the future development of African theology' (Cone 1979:183). Sadly or even tragically, in South Africa, this appears as true today, 25 years into democracy, as it was in 1977. The disillusionment with the idea of theologians' "“critical solidarity" with the [democratic] government' (Kumalo 2007:4-5), and the political ideology of rainbowism in general, is still to take effect in many theological circles in our country (cf. Urbaniak 2018c). Perhaps this strong liberationist motif would allow one to situate Cone's BT in the same trajectory as fallism, a new form of radical anti-racist politics in the present-day South Africa. This parallel is, however, substantially limited by other factors discussed above.

Thesis two: For Christian theology to be decolonised, African religiosity needs to be considered as a multifaceted phenomenon in its own right and engaged as a proper theological locus, also by white theologians.

Decolonisation entails unlearning Christianity, which has been justifiably described by Antonio (2018) as 'one of the most powerful colonial and oppressive structures of modernity'. Against such a backdrop, black religion with 'the religious image and historical reality of Africa' (Long 1995:110) as a vital aspect of its substratum - can be seen as an anti-modern instrument. It denounces 'deathdealing systems of power and exclusion', notably whiteness, and reclaims the flow of history 'in the name of a new humanity (God's ongoing creation of blackness)' (Antonio 2018). Speaking from a Caribbean perspective, Noel Erskine (1981) points out that:

$[T]$ here is a logical step from a consideration of black religion to an articulation of a theology of freedom, because black religion is black people's search in history for freedom. (pp. 118-119)

I believe that in principle Cone would not be opposed to such a liberationist interpretation of black religion (cf. Urbaniak 2018b). However, because of his firm belief that 'the universal dimension of the Gospel [Christianity]... transcends culture [Africanness, among others]', Cone (1979:180) was on the defensive about a distinctly Christian identity that BT developed within a broader framework of black religion. This was the source of his suspicion towards a broad and pluralistic notion of black religion inclusive of ATR. His main concern was that grounding black religion in African religiosity could lead to loosening African Americans' 'identity with the faith of the black church ... as if ATRs could replace Christianity for blacks in North America' (Cone 1986:98). This suspicion remained a distinguishing mark of his attempts to navigate the twofold identity of BT: Christian and African (Urbaniak 2018:177).

Here, I am focussing on the indigenous African contexts and aspects of black religion which Cone always saw as being in tension with Christianity. I want to argue that Christian theologians' unapologetic engagement with ATR considered as a proper theological locus may be interpreted as an (more or less covert) act of resistance against Christian imperialism. More specifically, such an engagement amounts in principle to an act of resistance against the persistent quest of white Christian theology during the colonial era to erase African aspects from the religious horizon of Africans. This quest continues in the 21st century, as Vellem (2014:1) points out, in the form of the generally more concealed and sophisticated assault on the imagination and consciousness of black Africans. In this context, African Initiated Churches (AICs) appear as the purest expression of African Christianity and living proof that 'African cultures can be a legitimate host, home and "container" for Christ just as Europe and Europeaness have been for ages' (Urbaniak 2016:143; cf. also Maluleke 1994:53). The praxis of AICs is now regarded by an increasing number of theologians, 'not only as the best illustration of African Christianity, but also as "enacted," "oral," or "narrative" African theology' (Maluleke 2005a:486). After the distinct phases of African theology's reflection on African religiosity, in the last few decades 'the AICs had been [explicitly] linked to praxis and thus the tradition of liberation and resistance' (Vellem 2014:3).

First of all, it should be noted that there are a number of scholars of religion who see the development of AICs as emanating from failure by Christian missions in adapting 
the gospel to the religious context of Africa' (Ndlovu 2014:55; cf. Engelke 2007:5; Kirby 1994:60ff; Ranger 2005:2). In his theory of vernacularisation, Lamin Sanneh gave an example of how the activity of AICs succeeded in defying the imperialistic claims inherent in Western Christianity. He (Vellem 2014; cf. also Sanneh 2001:17) argued that:

$[T]$ he mother tongues in the translation of the Bible paradoxically consigned primacy to black African originality and agency and continue to undermine the arguments that seek to present Western cultural dispensation as superior. (p. 3)

Kirby reminds us that the missionaries were generally 'too busy suppressing traditional rituals and beliefs' (1994:60) to come up with any balanced view of ATR. The missionary attempt to evangelise Africa implied dismantling the indigenous cultural and religious dispensation of black Africans (Vellem 2014:3). As Kirby (1994) points out:

With few exceptions, missionaries saw African traditional religions as a 'morass of bizarre beliefs and practices'... As a general principle we can say that before 1960 all mission-founded churches insisted that their converts abandon all contact with African traditional religions and cultures. These churches were poorly prepared theologically and culturally to accept any alternatives to their own way of praying, thinking and behaving. (pp. 60-61)

Chari (2014) takes issue with the marginalisation of AICs and ATR in the current African contexts, focussing on media representations of African religiosity. He points out that 'the "crowding out" of some religious denominations by mainstream and Pentecostal churches does not augur well for a society yearning for religious diversity' (Chari 2014:114). Probing 'various levels of implicit and explicit religious ethnocentricity' in the local media, he (Chari 2014) observes:

In Zimbabwe ... there is a tendency to portray some religious denominations, particularly African Independent Churches and African Traditional Religion as mysterious, inferior or simply evil. For example, African Traditional Religion (ATR) is equated with witchcraft, the same way as African Independent Churches are constructed as suspect. (p. 120)

In his discussion about the theological issues that emerge in the encounter of Christian faith and ATR, Kwame Bediako (1995:210-230), unsurprisingly, gives special attention to the place and significance of the ancestors. In tune with Nana Addo Dankwa, he asserts that 'Christian theology of ancestors in relation to the Christian community is unavoidable' (Bediako 1995:223). In this context, he points out that the 'specific value [of] the missionary dimension of the local Christian history' can be discerned only 'within a

5.Chari $(2014: 120)$ gives a telling illustration of that tendency when he refers to a story titled 'Big Indaba for witches' which was published in Parade Magazine of December 2000. The article described 'traditional healers who Pathered in 2000. The article described "traditional healers who gathered in Harare in 2000 to exhibit their wares ... as "witches" and "wizards"' (Chari 2014:120). In the same edition of the magazine, a Christian Pastor, Larry Ekanem, who performs miracles was labelled 'The Anointed Man ' article Ekanem insinuated that 'Zimbabwe is facing daunting economic and political challenges because its people have embraced practices like totems, thus, alienating themselves from God' (Chari 2014:120). religious history which truly belongs to the African tradition' (1995:226). More fundamentally, Bediako (1994) posits that:

Beginning from the basic apprehension of the universe as a unified cosmic, essentially spiritual, system ... the primal imagination (inherent in ATR) could help us avoid dichotomies in epistemology and so offer guidance towards an organic view of the knowledge of truth - increasingly felt to be desirable in Christian theology. (p. 210)

However, in the end, Bediako, like Harold Turner and some other African theologians, does not move beyond the understanding of ATRs as preparatio evangelica, a preparation for the gospel. On the other side of the spectrum are those African thinkers, Christian and non-Christian alike, 'who have argued that, not only has Christianity brought nothing "new," but that ATRs are superior to Christianity' (Maluleke 2005a:478). No wonder some African Christian theologians, especially Evangelicals, have been greatly troubled by such claims (Bediako 1994:14-20). Somewhere between these two extreme views, we find theologians such as Gabriel Setiloane, Christian Gaba, Bolaji Idowu and Samuel Kibicho among others, who urged African theology to suspend "any "evangelical" or "missionary" motives' in its attitude towards ATR (Maluleke 2005a:478). For instance, Setiloane (1979), while acknowledging and owning his African identity unconditionally, describes his (more problematic) Christian identity thus:

I am like someone who has been bewitched, and I find it difficult to shake off the Christian witchcraft with which I have been captivated. I cannot say I necessarily like where I am. Second, I rationalize my position by taking the view that to be Christian I do not have to endorse every details of western theology. (p. 65)

Somewhat similarly, Vellem (2014:6) posits that the Gospel itself requires to be 'salvaged from the ascendancy of a particular form of civilisation that has been obstinately portrayed as the only truthful mediation of life in the 21st century'.

More recently, the reflection on African culture and ATR has been framed by Tinyiko Maluleke (2005a:477) to include contemporary African perspectives. To Maluleke, African religiosity is 'the womb out of which African Christian theology must be born'. He is critical of reducing ATR to the status of preparatio evangelica, which in most cases amounts to 'a veiled refusal' to accept ATR on their own terms, what Okot p'Bitek as early as 1970 termed 'intellectual smuggling' (Maluleke 2005a:478). Thus, Maluleke (2005a:480) sees 'the non-Christian concern [of African theology] as the sign of realism and maturity'. ${ }^{6}$ This is why he prompts African theologians to 'listen anew to the critiques that have been levelled against African Christian theology by (apparently) non-Christian Africans such as $\mathrm{P}^{\prime}$ Bitek and others' (Maluleke 2005a:481; cf. also Mugambi 1992).

Furthermore, as Maluleke (2010) points out:

[T] he idea that Christianity could be Africanised has been viewed as suspect - either because it is assumed that Christianity

6.Maluleke (2005a:480) makes the point that African theology has never been just Christian theology as from its earliest times it has sought to dialogue with ATR and make sense of the complex world of African religiosity and culture. 
is universal or that Africanisation can only mean a lowering of universal 'Christian standards' in order to fit in with some local 'African standards'. (p. 372)

\section{But even (Maluleke 2005a):}

$[T]$ o posit the Africanisation of Christianity as the new task facing African theology [after the centuries of 'Christianising' Africa] may not, in reality, be as groundbreaking as it appears. (p. 480)

This is because juxtaposing Christianisation and Africanisation (Maluleke 2005a):

[A]ppears to rest on too rigid a separation between that which is Christian and that which is African (...) [In fact,] the two processes... have not and cannot be artificially separated. (p. 480)

Elsewhere Maluleke (2005b:123) takes his argument a step further to argue that African Christianity ought to be treated not merely as 'a battleground for Africanity and Christianity', but as a new coherent African religion, a religion in its own right. In the same vein, Mercy Amba Oduyoye (2017:477; cf. also Urbaniak 2018a:135) suggests that 'Christianity should be accepted as one of the "traditional religions" of Africa'.

Vuyani Vellem offers, in turn, a vital insight into liberation spirituality $^{7}$ and its locus in African religiosity. Similarly to some of the authors cited earlier, Vellem puts the pluriversal above the universal. He argues that 'African religiosity does not require inclusion in Western frameworks but equal recognition as a value system amongst others' (Vellem 2014:1). But his reflection goes deeper as he explores the spirituality of African religiosity expressed through the AICs and the resources it offers for 'cultural liberation, African history, black African agency and moral consciousness' as well as - what appears as the most original and captivating part of his argument - for an 'alternative civilisation' in the context of a 'death dealing culture of the empire in the 21st century $^{8}$ (Vellem 2014:1;4).

Vellem (2014:1) starts with the assertion that the modernist ethos brought to Africa by the missionaries as part of the colonial enterprise, 'not only disrupted the norms and values of the life of black Africans, but also their spiritual dispensation'. Thus, the beginning of the destruction of African civilisations is inextricably tied to the ascendancy of capitalist modernity and the expansion of Western Christianity. And yet Vellem (2014) argues that:

African religiosity maintained the sanity of the African soul within the underbelly of modernity. The narrative of the AICs is an expression of this spirituality of sanity in the context of a political, economic, spatial and cultural domination of a

7.Following Anderson (2000:17) among others, Vellem uses the concepts of African religiosity and spirituality synonymously.

8.Vellem uses this term, which is present in the Accra Confession, in the sense attributed to it by Ninian Koshny. The latter refers to empire to 'define the character of the 21st century as a convergence of military power, politics, economics and culture' (Vellem 2014:3; cf. also Koshny 2006:336). salvationist religion of the West ironically experienced as terror by black Africans. (p. 2)

Commenting on the more sophisticated strategies assumed by the 21st-century empire to subvert, if not to dismantle and destroy, the totality of the black African dispensation, Vellem (2014) probes, among other imperial strategies, inclusion as the subversion of Africanness. Inclusion can be 'deadly as it might simply imply assimilation and ultimately the death of consciousness' (Vellem 2014:4). ${ }^{10}$ This is why (Vellem 2014):

Black Consciousness requires one to grasp the internal logic of Western superiority and debunk it. Then rise above the falsely assumed inferiority of blacks: hence the affirmation of blackness and, ipso facto, the equality of intelligent and moral forms of knowledge that are originally black African with any other forms of knowledge. (p. 4)

As he examines the developments in the contestation between the West and Africa, Vellem (2014:5) maintains that 'black Africans had learned how to "colonise" for their own liberation the same instruments - Christianity in particular misused by the colonisers to subjugate them'. Against this background, enculturation, liberation and reconstruction which mark the major stages in the methodological development of African Christianity - should be seen as 'hermeneutic procedures that have sought to understand the cultural-political reality of black African people and thus African religiosity' (Vellem 2014:5) and to interpret this reality 'in the light of the gospel of Jesus, so as to bring about social and political transformation' (Dedji 2003:262).

Lastly, Vellem puts forward his proposal regarding African spirituality as a resource for an alternative civilisation. He contends that, as for black Africans, the whole of life is infiltrated by spirituality, and any pondering of African spirituality without considering the lives and struggles of the poor 'remains pie in the sky' (Vellem 2014:6). Unlike many Western forms of Christian spirituality marked by artificial dualities, African spirituality is 'the soul of culture and embraces one's whole religious experience - beliefs, convictions, patterns of thought and emotions - about the ultimate understanding of the transcendent' (Vellem 2014:6). Further, he (Vellem 2014) deems African religiosity as:

$[A] n$ important asset for life-giving spirituality amidst the secularised eschatology of the global market ... [and thus] a basis from which Christ's Gospel could be 'saved' from the claws of empire. (p. 6)

Vellem (2014) reiterates his central point by saying:

No amount of prejudice will disqualify African religiosity as an expression of the struggle for life, sanity and liberation against

9.Vellem's (2014:2-3; cf. also Vellem 2013) insights into mokhukhu (a 'shack' and, at the same time, 'a symbol of the spirituality for black Africans') offer a fascinating illustration of 'the sanity of the African soul within the underbelly of modernity'. He views mokhukhu as an expression of indigenous culture and spirituality... a spirit that refuses to be killed by the existential challenges and failures resulting from the that refuses to be (Vellem 2014:3)

10.With Cornel West, Vellem asserts that, if liberation consists of including black people within the mainstream of liberal capitalist America, then black theologians people within the mainstream of liberal capitalist America, then black theologians
better "drop the meretricious and flamboyant term "liberation" and adopt the better 'drop the meretricious and flamboyant term "liberatior
more accurate and sober word "inclusion"' (West 1979:556). 
the perpetual desire to subvert, drain and destroy the historical memory of black Africans. If the imago Dei... is the basis of equality of all cultures, its inclusion in the family of Christ, sola fide, is meaningful with African religiosity as its indispensable component, at least in South Africa. (p. 7)

There are a number of reasons why I believe white theologians should not be excluded from the call to engage African religiosity as a multifaceted phenomenon in its own right and as a proper theological locus. The most pragmatic reason is that we - white theologians who live in Africa and who (for better or worse) are actively involved in teaching and research - are the ones who need to be decolonised as a matter of urgency. But there is also a more substantive reason which justifies extending the call in question beyond the white theologians in Africa. As I argued elsewhere (Urbaniak 2018a):

Giving preference to the local ... appears to be a prerequisite to a dialogue with Western theological tradition in which the margins can speak to the centre as equals. However, if such a conversation is not to degenerate into a pseudo-contextual theologising, whereby the voices from the margins are seen as a mere expression of the global and are measured by its standards, both sides should remain mindful of the power dynamics still at work in academic and, more broadly, cultural domains. (p. 139)

From this point of view, an engagement with African appropriations of Christian message, 'wherein the deliberate act of resisting imperial forces is ingrained in the very fabric of theology, can prove a useful exercise in self-awareness also for Western theologians' (Urbaniak 2018a:139). Maluleke (2016) observes that Africans do not enter the struggle against dehumanisation as healthy warriors ready for battle, but rather as wounded souls at the risk of further injury. 'For centuries', Maluleke (2016) argues:

$[B]$ oth African religion and African culture have been weapons of resistance as well as arenas of the battle for the soul of Africa(ns) in the military, spiritual, and cultural assault on Africanness. (p. 3)

This is why, I believe, the African appropriations of Christian faith, as diverse as they are, essentially can be seen as 'battle theologies'. As such, they are concomitant with Jesus' own life which was (Urbaniak 2018a):

[T]he life of solidarity with the victims of oppression and misfortune, of brokenness and rejection, but also of resistance and struggle against the hypocrisy of the religious establishment and social injustice. (p. 137)

This is why engaging with African 'battle theologies' may urge especially the mainstream (mostly white and male) theologians to honestly probe the dynamics of power and difference inherent in their own theologising. Further, it may provide 'a wonderful stimulus [for them] to become more susceptible to the cries of the African cross-bearers beyond Africa, the cries that otherwise are often deliberately unheard' (Urbaniak 2018a:139).
Thesis three: Engaging African religiosity as a vital aspect of decolonising Christianity in a context like ours may be fostered by problematising the relationship between the categories of blackness and Africanness and thus also by rethinking the dichotomy of whiteness and blackness as a key theoretical lens for BT in South Africa, post-1994.

To close the loop, let me say a few words about the relationship between the categories of blackness and Africanness (Africanity) considered from Cone's US perspective, in juxtaposition with the racial dynamics in Brazil, and finally in the context of BT's fixation on the binaries of whiteness and blackness.

As I suggested elsewhere, in my view, Cone's difficulty with the Africanness as such was rooted ultimately in his ambivalent sense of his own identity (Urbaniak 2018b:177). Based on his writings, it is clear that the category of blackness sat much more comfortably with him than that of Africanness. Cone rejects the pigmentalist view of BT. He uses blackness as an abstract term, which has 'very little to do with the skin colour' (Cone 1997:151). Rather, it refers to the realities of oppression and dehumanisation experienced by a wide range of people around the world (Cortez 2016:199). Even if it is true that in the depths of his being Cone (1986:97) felt 'more African than European', it would not be unjustifiable to claim that, in his intellectual expression, he was more black than African. His black identity, 'so inextricably tied to North America' (Cone 1979:177), was the source of Cone's deep existential conflict inherent in his 'double identity as American and African'. While describing the nature of this conflict, Cone recalls Du Bois' classic remarks about the 'double consciousness' and 'twoness - an American, a Negro; two souls, two thoughts, two unreconciled strivings; two wanting ideals in one body, whose dogged strength alone keeps it from being torn asunder' (Du Bois 2018:3; cf. Cone 1979:177).

We should remember that an 'epistemic break' occurred in the United States in the late 1960s and early 1970s. The way blackness and Africanness were understood in the aftermath of Malcolm X and Black Power was dramatically different. Black Theology was born precisely in that climate. Malcolm's 1964 proclamation that black people born in America are not Americans, but Africans who 'happen to be in America' (Malcolm X: 1964) $)^{11}$ was truly bone-shaking. As Rickford (2016) points out:

The Black Power Movement's quest to concretize the ideals of blackness and Africanness that had been rekindled by the Mass movements of 1960s... signalled a strategic and philosophical shift from the pursuit of reform within a liberal democracy to the attempt to build the prospective infrastructure for an independent black nation, an entity that many activists imagined as a political and spiritual extension of the Third World [sic]. (p. 3)

11.In this historical speech, Malcolm X (1964:n.p.) proclaimed: 'We are a people who formerly were Africans who were kidnaped and brought to America ... We were brought here against our will; we were not brought here to be made citizens. We were not brought here to enjoy the constitutional gifts that they speak so beautifully about today' 
In this context, Rickford (2016:4) speaks of 'a mystique of global blackness and invented Africanness' as categories that underlay many of the Pan-Africanist and black nationalist projects over the course of 1970s.

But for the protagonists of the black renaissance confronted by the deep crisis of the African American identity, the opposite was true. It was 'the conscious recognition of historical memory' that Malcolm X and others considered 'a necessary first step in the process of transforming the negativity associated with a colonised mentality and psychea situation leading ultimately to ... mental, spiritual and psychological freedom' (Singh 2004:20).

In the texts and manifestos of that era, the two identity signifiers - Africanness and blackness - often seem to be used almost synonymously. And yet, though organically connected, these notions carried different meanings. Africanness and Africanisation were the central themes of the Pan-African nationalist rebirth. Within the North American context, Africanisation signified revival and cultivation of essential black cultural traits, behaviours and political values, thereby 'saturating black America with particular cultural symbols' (Rickford 2016:150). Analogically, the notion of Africanness referred to the African heritage shared by people of African descent all over the world. Blackness, in turn, emerged as a universalised identity signifier that transcended the realities of time and place pointing to a transnational black solidarity (Rickford 2016:82). Cornel West (1994:39) notes that unlike Africanness, which does not have a clear binary opposite, 'blackness is a political and ethical construct', which is always understood dialectically, in relation to whiteness, and, as such, it 'has no meaning outside of a system of race-conscious people and practices'.

The tension between the two categories is well captured in a contemporary voice from the Black Youth Project. Equating the creation of the category of blackness to the zombification of the black body, the author (Ureña-Ravelo 2017; cf. also Brown 2017) states thus:

Our colonisation was the possessing of our bodies and the attempted destruction of our ties and roots to our homelands, so as to make us rootless. If a person has no name, no mother, no tongue, no tribe, no land, no people, she can be whatever you tell her to be - chattel, slave, 3/5ths, alligator bait, nothing. An Indigenous person with the distinct memory of her land, of where she was taken from, is a force to be reckoned with, and that was recognized by those who stole us. And that is what sprung the creation of Blackness, the necessary death of the African to create a past-less, futureless dark malleable abyss in her place. A dark void from which can be wrought or sprung cotton, indigo, sugar, gold, pleasure, and labour from an enslaved workforce. (n.p.)

This is of course only one of the many possible interpretations of the two notions in question. Others suggested, for instance, that while blackness, as an identity signifier, serves the cause of the liberation of black people all over the world, the focus on Africanness usually coincides with subordinating 'liberation to matters of genealogy and kinship' (Rickford 2016:242) and thus may lead to the nationalistic 'deployment of a "race-culture" essentialist discourse' (Singh 2004:18). I imagine that Cone himself would be sympathetic to this view.

Even though the notion of blackness seems to have stronger claims to universality than that of Africanness, the experience of blackness in today's world is anything but homogenous. Various 'hierarchies of blackness exist throughout the colonized world' (Neason 2018). Apart from different shades of blackness (here in terms of pigmentation) being associated with different social status depending on the cultural context, one of the many other examples of this hierarchical notion of blackness is the fact that, 'when traveling abroad Black people from the West are often treated more favourably than Black people local to the area or from the Continent' (Neason 2018). It is evident even based on these few illustrations that often 'Africanness' of black people (the discernible degree or character thereof) is what determines their place in the hierarchy of blackness.

Sheila Walker offers an in-depth analysis of the tension between Africanity and blackness as she reflects on race, class and culture in the present-day Brazil. Particularly interesting is her juxtaposition of the Brazilian and the US contexts (Walker 2002):

$[I] n$ Brazil only a minority of the population is referred to as either black or white because Brazil does not have only the two polar and hermetic categories of the United States, but acknowledges linguistically as well as conceptually all the nuances of hue between the two that exist in reality. (p. 18)

As a result, unlike in the United States where citizens are clearly colour-coded and labelled by both society and the state as black or white (there can be no 'plain Americans'), in Brazil it is actually possible for people to consider themselves just Brazilian. The efforts of the Brazilian government to officially create an intermediate 'mixed' category have failed. Thus, Brazil's intermediary categories are still considered black.

Not surprisingly, for many Brazilians, the North Americans appear too racially conscious, rigid and segmented. Some African Americans from the United States, on the other hand, tend to see the racial dynamics in Brazil as hypocritical.

Regarding Africanness, the difference between the two contexts is more than clear. Some African Americans plainly deny their Africanness because of the negative images of Africa with which they have been assaulted by both mass media and the educational system. Even though African American and all-American culture contains many more Africanisms than are generally known and acknowledged, 'most African-Americans are not aware of them and so do not claim their Africanity' (Walker 2002). Most AfroBrazilians, on the other hand, have maintained a great deal of obviously African culture because the African presence 
remains an integral, defining and acknowledged component of Brazilian culture. The Afro-Brazilian relationship to Africa (and to Yoruba culture in particular) is direct and specific. The same applies even to most Brazilians who are white by both Brazilian and US standards. As a consequence, if African Americans want to claim their African roots, they would seek them across the ocean, whereas most Afro-Brazilians live an obvious continuity with their African legacy and thus can find those 'roots' in their home or neighbourhood. In Walker's (2002) words:

\begin{abstract}
Many African-Americans are currently seeking to reconnect with an ancestral heritage that has become foreign. [...] Although elements of African culture have survived in African-American religion, music, dance, crafts, language, gastronomy and aesthetics, as is especially evident in some areas of the south, the African culture to which most African-Americans look for roots, identity, and inspiration is something foreign rather than a part of their everyday experience. (...) [By contrast], for many AfroBrazilians, culture of obvious African origin exists overtly in their everyday environment. (...) [Their] African heritage... has never been alienated from them or them from it, although they found it necessary to resort to camouflage and/or compromise to preserve their religious culture, for example.
\end{abstract}

Walker concludes her study by drawing readers' attention to an increasing convergence between Africanness and blackness in both, Brazilian and North American, Africandescended populations. In her view, this process has its roots in Walker (2002):

$[T]$ heir reciprocal influences on one another as well as... the increased contact by both with Africa and the rest of the African Diaspora. Thus Afro-Brazilians are claiming their blackness and African-Americans are claiming their Africanity, often with each other as both mirror and inspiration.

Without engaging here in an in-depth analysis of racial dynamics and the relationship between blackness and Africanness in South Africa, ${ }^{12}$ suffice it to say that our cultural and political reality contains some features of both the Brazilian and the US contexts, and others that are uniquely South African.

Even though in the context of the struggle against the institutionalised apartheid and in its aftermath, the political category of blackness proved capacious enough to include minorities such as Indian and Chinese people, the current racial tensions make it clear that in South Africa post-1994, the concept of blackness is anything but homogenous, and the nuances of hue between the different 'shades' of blackness become increasingly distinct. The rising ethnic and racial autonomy of the mixed-race community and the politically fed hostility between the black and the Indian people are just two cases in point.

There is no doubt that many black South Africans are susceptible to the old, colonially rooted tendency (or trend) of cultural 'whitening'. But this tendency is radically

12.For such an analysis, I refer the readers to, among others, Paphitis and Kelland (2017); Maposa (2016); Singh and Bhana (2015); Memela (2015); Park (2011); Anon. (2010); Farred (2006); and Kanneh (1998). challenged by the growing movement of reclaiming both blackness and Africanness (as mentioned before, currently this dynamic is most tangible in the various \#MustFall youth formations that carry out the decolonial project in the country). These two tendencies coexisting in the South African society may partly explain the polarisation of the black community.

Most black South Africans have never been completely alienated from their cultural origins; 'Africanness' has continued to exist overtly in their everyday environment. And yet many find it (still) necessary to resort to some sort of camouflage, compromise or even double-consciousness and cultural schizophrenia in order to preserve their heritage on the one hand, and to survive in the public spaces (still) dominated by whiteness, often in the most implicit and sophisticated ways, on the other hand.

In the attempt to situate the South African BT within this complex picture, I should probably start by stating that black consciousness and BT appear as parallel movements that revolve around the binary view of blackness and whiteness. Just as black consciousness approach 'would be irrelevant in a homogeneous, non-exploitative egalitarian society' (Biko 1974:36), so BT, as a theological response to the challenge of white theology, 'would have been irrelevant in a homogeneous non-exploitative, egalitarian society' (Tshaka \& Makofane 2010:534). Black theology's grounding in blackness, as well as its critique of whiteness, requires whiteness as its binary 'other' (Antonio 2018). This is true of Cone's BT as well as its younger South African sister. Indeed, the firm establishment of Cone's project was made possible by 'the collective enunciation of an emerging discourse which unashamedly asserted blackness as a theological category' (Antonio 2018:n.p.), and this was done in a dialectical tension with the negative task of BT, namely, 'exposing the culpability of whiteness as a death-dealing system ... uncovering its social basis'. Antonio (2018) further elaborates:

One of the most radical aspects of Cone's thought was its refusal to countenance the possibility of a bridge between blackness and whiteness built on neutrality ... Whiteness is signifier ... Black theology itself cannot be understood without whiteness. Indeed the nature of Cone's critique and criticism of white theology presupposes a notion of whiteness. This binary is at the center of Cone's theology. (n.p.)

The critique of whiteness, which underpins the entire project of BT, is anthropological in nature. It calls into question the Christian faith's claim to universality, inclusivity and its redemptive character given its historic and historical participation in the exclusion of black humanity (Antonio 2018). Thus, it seems fair to say that since its beginning in the 1960s until recent times, the South African BT used the binary view of blackness and whiteness as its key theoretical lens.

And yet, at least during the past few years, in parallel with the decolonial narrative gaining increasing currency in both South African public life and academic discourse (chiefly because of fallism), a number of local black theologians have 
been engaging increasingly in the critique of rainbowism, post-1994 liberal capitalism 'trapped in the dictates of the Washington Consensus' (Vellem 2014:4), and modernist ethos at the service of the empire. ${ }^{13}$ Whiteness still features in this (relatively) new theological trajectory, but not as the necessary binary 'other' of blackness. Analogically, Africanness and African religiosity in particular are accepted as a proper theological loci, considered in their own right, without the need to define them in opposition to the West or the Euro-American modernist ethos.

It is worth noting that some of those theological voices entail a radical critique of BT itself. For instance, Kobo (2018:n.p.) deems BT's 'decentring of the androcentric, sexist conquering man... as bad as the conquering West if not worse'. However, while she (Kobo 2018:n.p.) claims that 'we can no longer critique the West but [must] debunk it', she does engage in a critical dialogue with BT and black consciousness. ${ }^{14}$ Along the same lines - though within the tradition of BT, rather than in opposition to it - Tshaka asserts that the relationship between Africanness and Christianity should be examined through the historical lens of Christian imperialism, which 'in essence contributed towards a flight from the black self. The repercussions of this have been devastating, as is evidenced by the Afrophobic attacks' (Tshaka 2010:124-125).

In the context of the shift in the South African BT, which I attempt to elucidate, Vellem's 2017 article on 'Un-thinking the West: The spirit of doing black theology of liberation in decolonial times' appears almost as a programmatic manifesto. Emphasising his locus of enunciation is Vellem's (2017) point of departure:

$[U]$ n-thinking the West is the idea we engage and propose as a culmination of my location, especially in the Faculty of Theology at the University of Pretoria. The idea is directly related to my life-long black assumptions (BC) and faith (BTL), black religiosity so to speak. (n.p.)

What follows is his (Vellem 2017, [author's added emphasis]) main thesis:

Rearticulating, reinterpreting or repeating the core ideas of BTL, whether by exponents of BTL, or outsiders and critics, takes the gains of the school backwards. It is as if by repeating its core ideas, BTL assumes the West as its 'non-believer', a quintessential contradiction. (p. 1)

13.cf., among others, Kobo $(2016,2018)$; Vellem $(2014,2015,2016,2017)$; Tshaka (2010, 2014, 2015); and Maluleke (2010, 2015). For instance, Vellem (2016:2), in (2010, 2014, 2015); and Maluleke (2010, 2015). For instance, Vellem (2016:2), in
one of his articles, elaborates on the isiXhosa notion of Imvuselelo (loosely one of his articles, elaborates on the isiXhosa notion of Imvuselelo (loosely
meaning revival or renewal) as 'part of the heritage of black theology of liberation bequeathed by the father of blackness and Africanity in South Africa', Tiyo Soga. He interprets Imvuselelo as a 'militant liturgical endeavour' in the face of the lethal assault on Africanness, including black African epistemicide and, indeed, the extinction of the African race (Vellem 2016:2).

14. Black theology and womanist discourses can be seen as compatible, in her view, only insofar as they expose and interrogate 'the triple and multiple jeopardy of race, class and gender in the oppression of black women' (Kobo 2018:n.p.). But, just as Biko's black consciousness fails - despite 'good exposition of constructed and castrated black men' - to articulate suffering of black women in the capitalist and white society, so the South African BT privileges certain oppressions and and white society, so the South African BT privileges certain oppressions and
struggles and neglects others. Because of this 'flaw at the philosophical level', struggles and neglects others. Because of this 'flaw at the philosophical level', vemonstrated in the phases and strands of the South African BT, patriarchal
violence continues to elude BTL even though it had nuanced patriarchy at its own violence continues to elude BTL even though
developmental stages' (Kobo 2018:n.p.).
Vellem $(2017: 1 ; 6)$ refers here to the West, not to whiteness, as he questions the relevance and usefulness of positioning the West as BT's 'non-believer', its binary 'other'. But logically the same point can be made, I believe, about whiteness as one of the chief driving forces behind the Western modernist ethos, or simply its synonym. By situating itself (or by being situated) within the dialectical framework whereby blackness cannot be conceived without its binary 'other', namely, whiteness and analogically whereby Africanness is being conceived exclusively in opposition to its binary 'other' (albeit less evident), namely, the West (or Europeaness) - BT undermines (or is being misrepresented by undermining) 'its independent conceptual existence', the fact that BT 'is both epistemologically and hermeneutically un-West' (Vellem 2017:1; 6).

Thus, un-thinking the West, as well as un-thinking the whiteness, indeed debunking them, appears as the only way for BT to point beyond - 'not in dualistic terms - the promises of white theology' (Vellem 2017:6). In positive terms, this would imply a comprehensive revalorisation of both Africanness and blackness, not as dialectical standpoints in the postcolonial critique of the West or whiteness but as autonomous categories in which the decolonial project aimed at debunking the West or whiteness should be grounded. From that perspective, it might be further argued that, because of its less (evidently) binary character, the notion of Africanness could be unshackled from its dialectic entanglement more easily than that of blackness.

\section{Acknowledgements Competing interests}

The authors declare that they have no financial or personal relationships which may have inappropriately influenced them in writing this article.

\section{Author's contributions}

J.U. is the sole contributor to this article.

\section{Ethical considerations}

This article followed all ethical standards for carrying out research without direct contact with human or animal subjects.

\section{Funding information}

This research received no specific grant from any funding agency in the public, commercial or not-for-profit sectors.

\section{Data availability statement}

Data sharing is not applicable to this article as no new data were created or analysed in this study.

\section{Disclaimer}

The views and opinions expressed in this article are those of the authors and do not necessarily reflect the official policy or position of any affiliated agency of the authors. 


\section{References}

Anderson, A., 2000, Zion and Pentecost: The spirituality and experience of Pentecostal and Zionist/Apostolic churches in South Africa, University of South Africa Press, Pretoria.

Anon., 2010, 'What Does Blackness Mean Now?', City Press 19 May, viewed 10 October 2018, from https://goo.gl/Bhm8gZ.

Antonio, E.P., 2018, 'Black theology as critical theology', Journal of Theology for Southern Africa 162, n.p.

Ashcroft, B., Griffiths, G. \& Tiffin, H. (eds.), 2006, Post-colonial studies reader, 2nd edn., Routledge, London.

Bediako, K., 1994, 'Understanding African theology in the 20th century', Themelios 20(1), 14-20

Bediako, K., 1995, Christianity in Africa: The renewal of non-Western religion, Edinburgh University Press, Edinburgh

Biko, S., 1974, 'Black consciousness and the quest for a true humanity', in B. Moore (ed.), The challenge of black theology in South Africa, pp. 36-47, John Knox Press, Atlanta, GA

Brown, S.J., 2017, “"Listen to the ancestors, Run!": Get out, Zombification, and pathologizing escape from the plantation', RaiceBaitR, 07 March, viewed 15 October 2018, from https://goo.gl/wN4W7u.

Comaroff, J. \& Comaroff, J.L., 1988, 'Through the looking-glass: Colonial encounters of the first kind', Journal of Historical Sociology 1(1), 6-32. https://doi. org/10.1111/j.1467-6443.1988.tb00002.x

Carr, B., 1974, 'The engagement of Lusaka', Assembly Secretariat, All Africa Conference of Churches, The Struggle Continues, Official Report of the Third Assembly of All Africa Conference of Churches, Lusaka, Zambia, 12-24 May 1974, All Africa Conference of Churches, Nairobi, Kenya, pp. 73-81.

Chari, T., 2014, 'Suspect spirituality'? Media representation of African independent churches in Zimbabwe', in E. Chitando (ed.), Multiplying in the Spirit: African initiated churches in Zimbabwe, pp. 109-128, University of Bamberg Press, Bamberg, Germany.

Chikane, R., 2018, Breaking a rainbow, building the nation: The politics behind \#MustFall Movements, Picador Africa, Johannesburg.

Cone, J.H., 1979, 'A black American perspective on the future of African theology', in K. Appiah-Kubi \& S. Torres (eds.), African theology en route, pp. 176-186, Orbis K. Appiah-Kubi \& S. To
Books, Maryknoll, NY.

Cone, J.H., 1986, My soul looks back, Orbis Books, Maryknoll, NY.

Cone, J.H., 1997, Black theology and black power, Orbis Books, Maryknoll, NY.

Conrad, A., Raatus, C., Khunoane, K., Ditsele, O., Mnqwazana, S., Mnisi, S. et al., 2017, The fall [the playscript of the 2016 Baxter Theatre production], Junkets Publisher, Pinelands, South Africa.

Cortez, M., 2016, 'The Black Messiah: Race, liberation and the actualization of humanity in James Cone's christological anthropology', in M. Cortez (ed.), Christological anthropology in historical perspective: Ancient and contemporary approaches to anthropology in historical perspective: Ancient and contemporary appro
theological anthropology, pp. 190-217, Zondervan, Grand Rapids, MI.

De la Campa, R., 2008, 'Postcolonial sensibility, Latin American, and the question of literature', in M. Morana, E. Dussel \& C.A. Jáuregui (eds.), Coloniality at large: Latin America and the Postcolonial debate, pp. 435-458, Duke University Press, Latin Am
Durham.

Dedji, V., 2003, Reconstruction and renewal in African Christian theology, Acton, Nairobi.

Du Bois, W.E.B., 2018, The souls of black folk, Myers Education Press, Gorham, ME.

Engelke, M., 2007, A problem of presence: Beyond scripture in an African church, University of California Press, Berkley, CA.

Engdahl, H., 2017, 'The Black Atlantic as reversal: A reappraisal of African and Black theology', HTS Teologiese Studies/Theological Studies 73(3), a4618. https://doi. org/10.4102/hts.v73i3.4618

Erskine, N.L., 1981, Decolonizing theology: A Caribbean perspective, Orbis Books, Maryknoll, NY.

Farred, G., 2006, '“Shooting the White Girl First": Race in post-apartheid South Africa', in D.A. Thomas \& K.M. Clarke (eds.), Globalization and race: Transformations in the cultural production of Blackness, pp. 226-248, Duke University Press, Durham.

Hume, P., 2008, 'Postcolonial theory and the postcolonial representation of culture in the Americas', in M. Morana, E. Dussel \& C.A. Jáuregui (eds.), Coloniality at large: Latin America and the postcolonial debate, pp. 388-395, Duke University Press, Durham.

Kanneh, K., 1998, African identities: Race, nation and culture in ethnography, Pan-Africanism and Black literatures, Routledge, London.

Kirby, J., 1994, 'Cultural change and religious conversion in West Africa', in T. Blakeley, W. Van Beek \& D. Thompson (eds.), Religion in Africa, pp. 57-72, James Currey, London.

Kobo, F., 2016, 'Umfazi Akangeni Ebuhlanti Emzini... a womanist dialogue with Black theology of liberation in the 21st century', HTS Teologiese Studies/Theological Studies 72(1), a3268. https://doi.org/10.4102/hts.v72i1.3268

Kobo, F., 2018, 'Womanism and Black anthropology: In memory of James Cone', Journal of Theology for Southern Africa 162, n.p.

Koshny, N., 2006, 'The global empire: An overview', Reformed World 56(4), 335-354.

Kumalo, S.R., 2007, 'A prophetic church in the democratization of the South African Society: A myth or reality', A Paper Delivered at Diakonia Council of Churches, 7th November, viewed 24 September 2016, from http://bit.ly/2dW7OAt.
Long, C.H., 1995, Significations: Signs, symbols, and images in the interpretation of religion, Davies Group, Aurora.

Malcolm, X., 1964, 'The ballot or the bullet', Speech Given on 29th March in Washington Heights, New York, viewed 10 October 2018, from https://goo.gl/ pvoJDs.

Maldonado-Torres, N., 2008, 'Secularism and religion in the modern/colonial world-system: From secular postcoloniality to postsecular transmodernity', in M. Morana, E. Dussel \& C.A. Jáuregui (eds.), Coloniality at large: Latin America and the postcolonial debate, pp. 360-384, Duke University Press, Durham.

Maluleke, T.S., 1994, 'Christ in Africa: The influence of multi-vulturity on the experience of Christ', Journal of Black Theology in South Africa 8(1), 49-64.

Maluleke, T.S., 2000, 'A historical quest for a Black presence that "Walks"', in P. Denis (ed.), Orality, memory, and the past: Listening to the voices of Black Clergy under colonialism and apartheid, pp. 229-250, Cluster Publications, Pietermaritzburg.

Maluleke, T.S., 2005a, 'Half a century of African Christian theologies: Elements of the emerging agenda for the twenty-first century', in O.U. Kalu (ed.), African Christianity: An African story, pp. 469-493, Department of Church History, University of Pretoria, Pretoria.

Maluleke, T.S., 2005b, 'African Christianity as African Religion: Beyond the contextualization paradigm', in M. Battle (ed.), The quest for liberation and reconciliation: Essays in honor of $J$. Deotis Roberts, pp. 116-126, Westminster John Knox Press, Louisville, KY.

Maluleke, T.S., 2010, 'Of Africanised bees and Africanised churches: Ten theses on African Christianity', Missionalia 38(3), 369-379.

Maluleke, T.S., 2015, 'Meet Tyranny with rage, not violence', Mail \& Guardian, 11 September, viewed 28 July 2016, from https://goo.gl/841NL3.

Maluleke, T.S., 2016, 'The good life and social justice in Africa', paper delivered at The Annual Meeting of the American Academy of Religion: African Religions Group and African Association for the Study of Religion, San Antonio, TX [unpublished], 21st November.

Maposa, M., 2016, 'The construction of the African being in South African history textbooks', Journal of Education 65, 5-30.

McKenzie, M., 2015, 'How to Tell the Difference between Real Solidarity and "Ally Theatre"', BGD ["Black Girl Dangerous"], 4 November, viewed 24 September 2016, from https://goo.gl/ZRZrNC.

Memela, S., 2015, 'True Africanness includes everyone', Sunday Independent, 24 May, viewed 10 October 2018, from https://goo.gl/rqU5Sf.

Mignolo, W.D., 2011, The Darker side of Western modernity: Global futures, decolonial options, Duke University Press, Durham.

Mugambi, J.N.K., 1992, Critique of Christianity in African literature, East African Educational Publishers, Nairobi.

Mumo, P.M., 2018, 'The reality of African Religio-cultural identity in the context of globalization', in E.K. Bongmba (ed.), Religion and social reconstruction in Africa, pp. 198-211, Routledge, Abingdon.

Ndelu, S., 2017, 'A rebellion of the poor: Fallism at the Cape Peninsula University of Technology', in M. Langa (ed.), \#Hashtag: An analysis of the \#FeesMustFall movement at South African universities, pp. 13-32, Centre for the Study of Violence and Reconciliation, Johannesburg.

Ndlovu, L., 2014, 'The African apostolic church led by Paul Mwazha as a response to secularization', in E. Chitando (ed.), Multiplying in the spirit: African initiated churches in Zimbabwe, University of Bamberg Press, Bamberg, Germany.

Neason, C., 2018, 'Call me Akata: Reclaiming our birthright as Indigenous and African people born on American soil', RaiceBaitR, 5 March, viewed 15 October 2018 , from https://goo.gl/wTH6qu.

Oduyoye, M.A., 2017, 'The future of Christianity in sub-Saharan Africa', in K.R. Ross, J.K. Asamoah-Gyadu \& T.M. Johnson (eds.), Christianity in sub-Saharan Africa, pp. 461-477, Edinburgh University Press, Edinburgh.

Paphitis, S. \& Kelland, L.-A., 2017, 'The Africanness of White Africans?', in R. Winkler (ed.), Identity and difference: Contemporary debates on the self, pp. 235-258, Palgrave Macmillan, Cham, Switzerland.

Park, Y.J., 2011, 'Black, yellow, (Honorary) White or just plain South African? Chinese South Africans, identity and affirmative action', Transformation 77, 117-131.

Ranger, T., 2005, Religion in Africa, A Series of Three Lecturers by Terence Ranger, Oxford Centre for Mission Studies, Oxford, UK.

Rickford, R.J., 2016, We are an African people: Independent education, Black power, and the radical imagination, Oxford University Press, Oxford.

Rohr, R., 2011, Falling upward: A spirituality for the two halves of life, Jossey-Bass, San Francisco, CA.

Sanneh, L., 2001, 'The African transformation of Christianity: Comparative reflections on ethnicity and religious mobilization in Africa', in D. Hopkins, L.A. Lorentzen, E. Mendieta \& D. Bastone (eds.), Religions/globalizations: Theories and cases, pp. 1-79, Duke University Press, London. https://doi. org/10.1215/9780822380405-007

Setiloane, G.M., 1979, 'Where are we in African theology?', in K. Appiah-Kubi \& S. Torres (eds.), African theology en route, pp. 59-65, Orbis Books, Maryknoll, NY.

Singh, S., 2004, 'Resistance, essentialism, and empowerment in Black Nationalist Discourse in the African Diaspora: A comparison of the Back to Africa, Black Power, and Rastafari movements', Journal of African American Studies 8(3), 18-36. https://doi.org/10.1007/s12111-004-1011-3

Singh, T. \& Bhana, D., 2015, 'Shifting race and class in student construction of identities at a South African University', African Identities 13(3), 199-210. https://doi.org/1 0.1080/14725843.2015.1074537 
Sithole, T., 2014, 'Achille Mbembe: Subject, subjection, and subjectivity', Doctoral thesis, University of South Africa, Pretoria.

Tshaka, R.S., 2010, 'Do our theological methodologies help us to deal with situations of violence in Black communities, specifically Afrophobia?', Journal of Theology for Southern Africa 138, 124-135.

Tshaka, R.S., 2014, 'On being African and reformed? Towards an African reformed theology enthused by an interlocution of those on the margins of society' HTS Teologiese Studies/Theological Studies 70(1), Art. \#2070, 1-7. https://doi. org/10.4102/hts.v70i1.2070

Tshaka, R.S., 2015, 'The Black Church as the Womb of Black liberation theology? Why the uniting reformed church in Southern Africa (URCSA) is not a Genuine Black Church?', HTS Teologiese Studies/Theological Studies 71(3), Art. \#2800, 1-10. https://doi.org/10.4102/hts.v71i3.2800

Tshaka, R.S. \& Makofane, M.K., 2010, 'The continued relevance of Black liberation theology for democratic South Africa today', Scriptura 105, 532-546. https://doi. org/10.7833/105-0-155

Urbaniak, J., 2016, 'What makes Christology in a post-apartheid South Africa engaged and prophetic? Comparative study of Koopman and Maluleke', in R. Venter (ed.), Theological disciplines and the (post)apartheid condition: Genealogies and future directions, vol. 1, pp. 125-155, University of the Free State: Theological Explorations, Bloemfontein.

Urbaniak, J., 2018a, 'Between the Christ of deep incarnation and the African Jesus of Tinyiko Maluleke: An improvised dialogue', Modern Theology 34, 1-29, viewed 24 January 2019, from https://goo.gl/nRGz2E.

Urbaniak, J., 2018b, 'Cone's binary view of Africanness and Christianity through the eyes of his African American critics', Missionalia: Southern African Journal of Missiology 46(2), 175-196. https://doi.org/10.7832/46-2-308
Urbaniak, J., 2018c, 'Elitist, populist or prophetic? A critique of public theologising in democratic South Africa', The International Journal of Public Theology 12(3-4) 328-348. https://doi.org/10.1163/15697320-12341546

Ureña-Ravelo, B.L., 2017, 'Stolen bodies, Stolen land: Contemplating blackness and indigeneity', Afropunk, 06 December, viewed 15 October 2018, from http://bit.ly/2Xs6xcJ.

Vellem, V.S., 2013, 'Reformed tradition as public theology', HTS Teologiese Studies/ Theological Studies 69(1), Art. \#1371, 1-5. https://doi.org/10.4102/hts.v69i1. 1371

Vellem, V.S., 2014, 'Spirituality of liberation: A conversation with African religiosity', HTS Teologiese Studies/Theological Studies 70(1), Art. \#2752, 1-7. https://doi. org/10.4102/hts.v70i1.2752

Vellem, V.S., 2015, 'Black theology of liberation and radical democracy: A dialogue', Scriptura 114(1), 1-13. https://doi.org/10.7833/114-0-1111

Vellem, V.S., 2016, 'Imvuselelo: Embers of liberation in South Africa post-1994', HTS Teologiese Studies/Theological Studies 72(1), a3501. https://doi.org/10.4102/hts. v72i1.3501

Vellem, V.S., 2017, 'Un-thinking the West: The spirit of doing Black Theology of liberation in decolonial times', HTS Teologiese Studies/Theological Studies 73(3), a4737. https://doi.org/10.4102/hts.v73i3.4737

Walker, S.S., 2002, 'Africanity vs. Blackness: Race, class and culture in Brazil', NACLA Report on the Americas 35(6), 16-20, viewed 10 October 2018, from https://goo.gl/98CAst.

West, C., 1979, 'Black theology and Marxist thought', in G.S. Wilmore \& H.J. Cone (eds.), Black theology: A documentary history, 1966-1979, pp. 552-567, Orbis, Maryknoll, NY

West, C., 1994, Race matters, Vintage Books, New York. 